\title{
Determination of myricetin derivatives in Chrysobalanus icaco L. (Chrysobalanaceae)
}

\author{
Wagner Luiz R. Barbosa ${ }^{1 *}$, Amiraldo Peres ${ }^{1}$, Sandra Gallori ${ }^{2}$, Franco F. Vincieri ${ }^{2}$ \\ ${ }^{1}$ Laboratório de Fitoquímica e Cromatografia Líquida de Alta Eficiência, Departamento de Farmácia, Universidade \\ Federal do Pará, 66075-110, Belém, Pará, Brasil, \\ ${ }^{2}$ Dipartimento di Scienze Farmaceutiche, Univeristà degli Studi di Firenze, Polo Scientifico di Sesto Fiorentino, Via \\ U. Schiff 6, 50100 Firenze, Italy
}

\begin{abstract}
RESUMO: "Determinação de derivados de miricetina em Chrysobalanus icaco L. (Chrysobalanaceae)". A fração flavonoídica do extrato hidroalcoólico de folhas de Chrysobalanus icaco L. (Chrysobalanaceae), que são largamente utilizadas na medicina tradicional do Norte do Brasil para controlar a glicemia de pacientes diabéticos, foi caracterizada. Miricetina-3-O glucuronídeo (miricitrina) e quercitrina, entre outros derivados de miricetina minoritários, foram evidenciados por análises com sistemas CLAE/DAD e CLAE/EM.
\end{abstract}

Unitermos: Chrysobalanus icaco, Chrysobalanaceae, miricetina, medicina tradicional, diabetes.

\begin{abstract}
The flavonoidic fraction composition of the hydroalcoholic extract of Chrysobalanus icaco L. (Chrysobalanaceae) leaves, which are largely used in the traditional medicine in Northern Brazil to control the glycaemia of diabetic patients, was characterised. Myricetin 3-O-glucuronide (miricitrin) and quercitrin, among other minor myricetin derivatives, were evidenced by HPLC/ DAD and HPLC/MS analysis.
\end{abstract}

Keywords: Chrysobalanus icaco, Chrysobalanaceae, myricetin, traditional medicine, diabetes.

\section{INTRODUCTION}

Chrysobalanus icaco L., also known as "coco plum", "icaco", "agirú", is an evergreen, medium-sized shrub or, rarely, a small tree with leathery, dark-green, round to oval leaves. The species is native to coastal areas of southern Florida, the Bahamas and through the Caribbean. It is also found through Central and South America, including Mexico, Ecuador and Northern Brazil as well as tropical Africa (Little et al., 1974).

The aqueous extract of Chrysobalanus icaco L. leaves (Chrysobalanaceae family) is commonly used in the traditional medicine in northern Brazil (State of Pará) to control the glycaemia of diabetic patients (Barbosa et al., 2001; Costa, 1977; Pereira, 1997; Barbosa-Filho et al., 2005).

To our knowledge only a few papers in the literature focus on the phytochemical investigation of Chrysobalanus icaco L. (Chaffaud; Emberger, 1960; Bate-Smith, 1961; Mendez et al., 1995; Coradin et al., 1985; Gunstone; Subbarao 1967; Verma; Raychaudhuri, 1972; Fernandes et al., 2003; Gustafson; Munro, 1991). The first phytochemical investigations reports the presence of myricetin in Chrysobalanus icaco L. (Chaffaud; Emberger, 1960) leaves. Thus, myricetin (Figure 1) is considered a primitive flavonoid character and its presence has been used as a chemotaxonomic marker in the Chrysobalanaceae family (Mendez et al., 1995; Coradin et al., 1985). In earlier works trienoic, tetraenoic acids and their oxo derivatives in seed oils (Gunstone; Subbarao 1967) and catechol tannins (Verma; Raychaudhuri, 1972) were found. Finally, the presence of diterpenes and triterpenes in the leaves of Chrysobalanus icaco L. were also reported (Fernandes et al., 2003; Gustafson; Munro, 1991).

HPLC has been effective in the analysis of flavonoids of plant extracts (Yariwake et al., 2005). A preliminary analysis, by HPLC-DAD, of Chrysobalanus icaco L. leaves showed the presence of rutin in the aqueous extract and tincture (Barbosa; Peres, 2002). To continue our studies on this plant, the hydroalcoholic extract of Chrysobalanus icaco L. leaves was investigated. Myricetin 3-O-glucuronide and other myricetin and quercetin derivatives were identified by HPLC/DAD and HPLC/MS analysis.

Traditionally $C$. icaco is used as an infusion but to be used in the pharmaceutical manipulation a tincture has more suitable physical and chemical properties. Once the results here reported can be useful for the registration of this plant species as a phytotherapeutic medicine according to the Brazilian Health Regulation we decide to investigate the tincture, whit an alcoholic content corresponding to 70 degree Gay Lussac. 


\section{MATERIAL AND METHODS}

\section{Plant material}

The Chrysobalanus icaco L. leaves were collected near to Belém (Pará, Brazil) in 2003. The plant material were identified by Dr. Mário Augusto Gonçalves Jardim of the Museu Paraense Emilio Goeldi in Belém, Pará and a voucher specimen is deposited under the number LAFQ-005 at the Laboratório de Fitoquímica e Cromatografia Líquida de Alta Eficiência, Departamento de Farmácia, Universidade Federal do Pará, Belém, Pará, Brasil.

\section{Chemicals}

$\mathrm{CH}_{3} \mathrm{CN}$ and $\mathrm{MeOH}$ (HPLC grade) were from Merck (Darmstadt, Germany); 85\% formic acid was provided by Carlo Erba (Milan, Italy). Water was purified by a Milli-Qplus system from Millipore (Milford, MA, USA). $0.45 \mu \mathrm{m}$ PTFE membrane filter was purchased from Waters Co. (Milford, MA). All laboratory chemicals used in this study were of reagent grade. Quercetin and quercetin 3-O-rhamnoside (quercitrin) authentic standards were purchased from Extrasynthese S.A.

\section{Sample preparation}

$20 \mathrm{~g}$ Dried and grounded leaves of Chrysobalanus icaco were extracted by maceration for 3 days with 200 $\mathrm{mL}$ ethanol $70{ }^{\circ} \mathrm{GL}$ to give the hydroalcoholic extract. The obtained tincture $(200 \mathrm{~mL})$ was evaporated under vacuum and lyophilized to dryness to give $1.95 \mathrm{~g}$ of a greenish yellow powder. $50 \mathrm{mg}$ of this sample were rinsed with $2 \mathrm{~mL}$ of $\mathrm{MeOH}$, then filtered through a 0.45 $\mu \mathrm{m}$ PTFE filter into HPLC vials directly and analysed by HPLC-DAD and HPLC-MS.

\section{Instrumentation and conditions}

HPLC-DAD analyses were performed on a HP 1090L Series II liquid chromatograph equipped with a diode array detector (all from Hewlett \& Packard, Palo Alto, CA, USA). Columns were 250 x $4.6 \mathrm{~mm}$ Synergy MAX RP-12 $(4 \mu)\left(\right.$ Phenomenex $^{\circledR}$, USA) and $250 \times 4.6$ mm LiChroCART ${ }^{\circledR}$ Purosphere STAR RP-18 $(4 \mu)$. The oven column was maintained at $26^{\circ} \mathrm{C}$.

The compounds were separated using $\mathrm{H}_{2} \mathrm{O}$ (adjusted to $\mathrm{pH} 3.2$ by $\mathrm{HCOOH}$ ), $\mathrm{CH}_{3} \mathrm{CN}$ and $\mathrm{MeOH}$; the applied linear solvent gradient is reported in Table 1. UV-Vis spectra were recorded in the range $190-450 \mathrm{~nm}$, and the chromatograms were acquired at 230, 254, 280, 330 and $350 \mathrm{~nm}$.

Mass spectra were performed using a HP 1100 MSD API-electrospray coupled with a HP 1100L liquid chromatograph equipped with a DAD detector (Hewlett \& Packard, Palo Alto, CA, USA). The interface geometry, with an orthogonal position of the nebulizer with respect to the capillary inlet, allowed the use of analytical conditions similar to those of HPLC-DAD analysis. The same column, mobile phase, time period and flow rate were used. Mass spectrometry operating conditions were optimised in order to achieve maximum sensitivity values: negative and positive ionisation mode (scan spectra from $\mathrm{m} / \mathrm{z} 100$ to 800 ) were used with a gas temperature of $350{ }^{\circ} \mathrm{C}$, nitrogen flow rate of $10.0 \mathrm{~L} / \mathrm{min}$, nebulizer pressure $30 \mathrm{psi}$, quadrupole temperature $30^{\circ} \mathrm{C}$, and capillary voltage $3500 \mathrm{~V}$. The applied fragmentors were in the range $80-150 \mathrm{~V}$. The orthogonal position of the nebulizer with respect to the capillary inlet allowed the use of the same conditions of HPLC/DAD analysis with $\mathrm{H}_{2} \mathrm{O}$ adjusted to $\mathrm{pH} 3.2$ by $\mathrm{HCOOH}$.

\section{RESULTS AND DISCUSSION}

Identification of constituents was carried out by HPLC/DAD and HPLC/MS analysis, and/or by comparison and combination of their HPLC retention times, UV-Vis and mass spectra with those of authentic samples and by comparison with the chromatogram obtained of a fully characterised extract of Pistacia lentiscus L. (Romani et al., 2002). For the characterisation of the compounds, the HPLC/MS analysis in negative and positive ion mode, applying different fragmentation energy, was a very useful tool.

The chromatographic profile reported in Figure 2 , acquired at $350 \mathrm{~nm}$, relative to the total hydroalcoholic extract from Chrysobalanus icaco L. leaves revealed the presence of several flavonoid derivatives such as myricetin 3-O-glucuronide, miricitrin and quercitrin, among other myricetin derivatives.

The peak recorded at Rt 24.33 min showed two major signals in the mass spectra: the peak corresponding to the quasi-molecular ion $[\mathrm{M}-\mathrm{H}]^{-}$at $\mathrm{m} / \mathrm{z} 493$ and the fragment ion at $\mathrm{m} / \mathrm{z} 317$ corresponding to the loss of glucuronic acid (Figure 3). By UV-Vis and mass spectra this compound was identified as myricetin 3-Oglucuronide and represents the major compound present in the extract.

The peak recorded at Rt 16.48 min showed two major signals in the mass spectra: the peak corresponding to the quasi-molecular ion $[\mathrm{M}-\mathrm{H}]^{-}$at $\mathrm{m} / \mathrm{z} 625$ and the fragment ion at $\mathrm{m} / \mathrm{z} 317$ corresponding to the loss of rhamnose unit. By UV-Vis and mass spectra this compound was identified as myricetin 3-O-rutinoside.

By UV-Vis, mass spectra and by comparison of the rutin authentic sample, the peak recorded at Rt 19.63 min was identified as rutin. These data confirmed the presence of rutin, previously identified in Chrysobalanus icaco L. (Barbosa; Peres, 2002).

The peak recorded at Rt $21.02 \mathrm{~min}$ showed two major signals in the mass spectra: the peak corresponding to the quasi-molecular ion $[\mathrm{M}-\mathrm{H}]^{-}$at $\mathrm{m} /$ z 463 and the fragment ion at $\mathrm{m} / \mathrm{z} 317$ corresponding to




<smiles>O=c1c(O)c(-c2cc(O)c(O)c(O)c2)oc2cc(O)cc(O)c12</smiles>

Figure 1. Structure of myricetin.

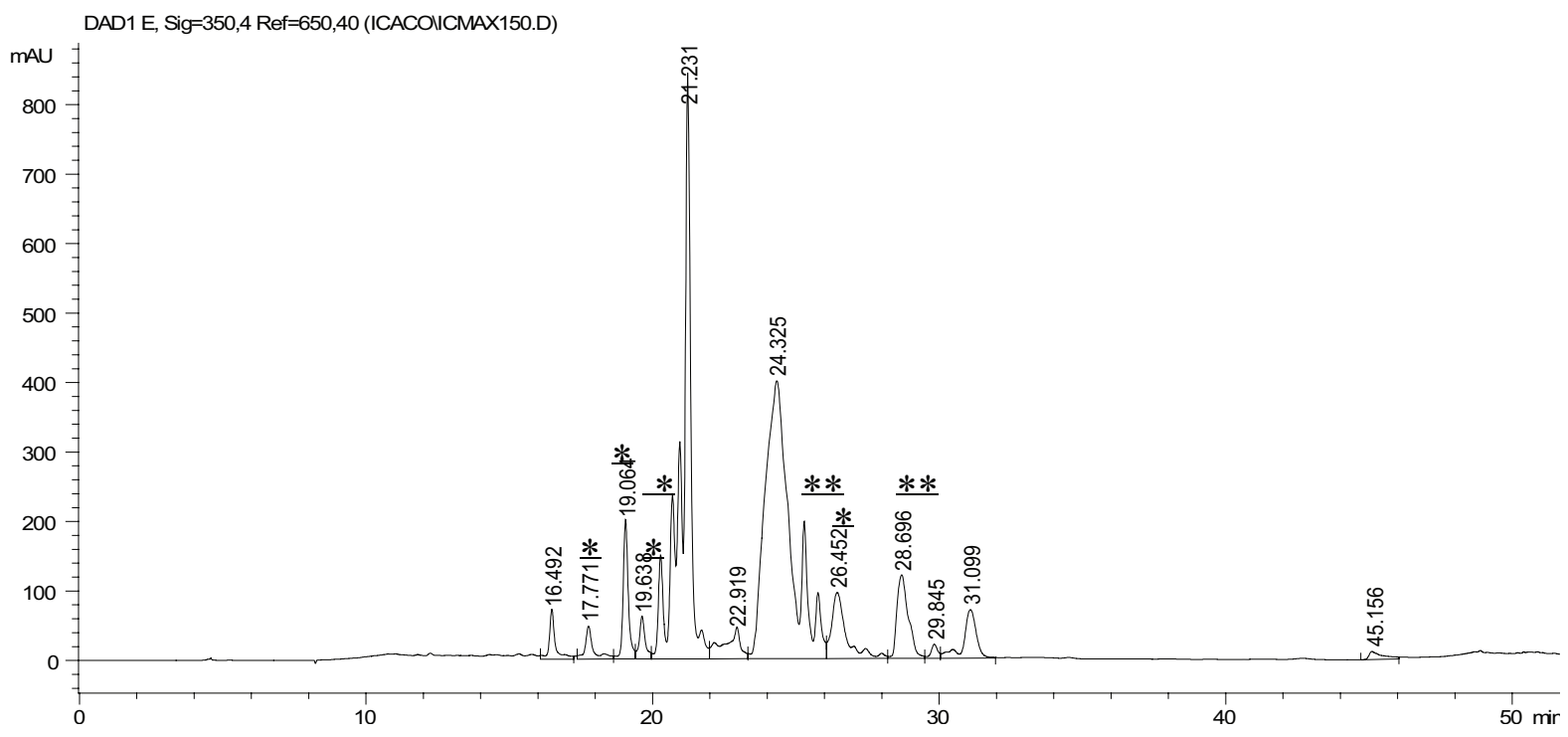

Figure 2. HPLC chromatograms acquired at $\lambda 350 \mathrm{~nm}$ of total hydroalcoholic extract of Chrysobalanus icaco L. leaves (column

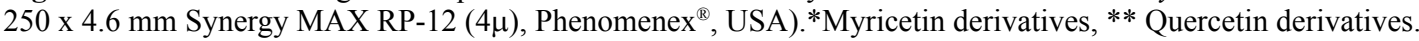

the loss of rhamnose unit. By UV-Vis, mass spectra and by comparison of the miricitrin authentic sample, this compound was identified as myricetin-3-O-rhamnoside (miricitrin).

The peak recorded at Rt 25.77 min showed two major signals in the mass spectra: the peak corresponding to the quasi-molecular ion $[\mathrm{M}-\mathrm{H}]^{-}$at $\mathrm{m} /$ z 447 and the fragment ion at $\mathrm{m} / \mathrm{z} 301$ corresponding to the loss of rhamnose unit. By UV-Vis, mass spectra and by comparison of the quercitrin authentic sample, this compound was identified as quercetin 3-O-rhamnoside (quercitrin).

Myricetin 3-O-rutinoside, myricetin 3-Orhamnoside, myricetin 3-O-glucuronide and quercetin 3-O-rhamnoside were also detected by comparison of Chrysobalanus icaco L. extract with a sample of Pistacia lentiscus L. extract where these compounds were previously identified (Romani et al., 2002).

Moreover, from the UV spectra and MS data, the presence of other myricetin derivatives i.e. myricetin bonded with a pentose unit and glucuronic acid (Rt 19.06 min), myricetin bonded with a pentose unit and rhamnose (Rt $20.69 \mathrm{~min}$ and Rt $21.23 \mathrm{~min}$ ); quercetin derivatives i.e. quercetin bonded with a pentose unit and rhamnose (Rt $25.29 \mathrm{~min}$ ); and a quercetin glucuronic derivative (Rt $28.69 \mathrm{~min}$ ) can be supposed (Figure 2).

Finally, as a further investigation on the presence of myricetin 3-O-glucuronide a LC-DAD and LC-MS analyses were also performed using a LiChroCART $^{\circledR}$ Purosphere STAR RP-18 column with the same analytical parameters of the previous HPLC analyses. Figure 4 shows the optimised chromatogram, acquired at $350 \mathrm{~nm}$, with the main peak at Rt $22.34 \mathrm{~min}$ corresponding to myricetin 3-O-glucuronide, as the mass spectrum allows us to deduce.

\section{CONCLUSION}

Using the LC-DAD-MS method, the presence of myricetin-3-O-glucuronide (miricitrin, as major constituent), quercitrin, and rutin, as well as other minor myricetin and quercetin derivatives in the hydroalcoholic extract of Chrysobalanus icaco L. leaves have been evidenced.

Using the $\operatorname{Star}^{\circledR}$ (RP-18) column, we observed a shift of Rts with respect to the Synergy MAX (RP- 
${ }^{*}$ MSD1 SPC, time=24.957 of ICACOIICMAX150.D

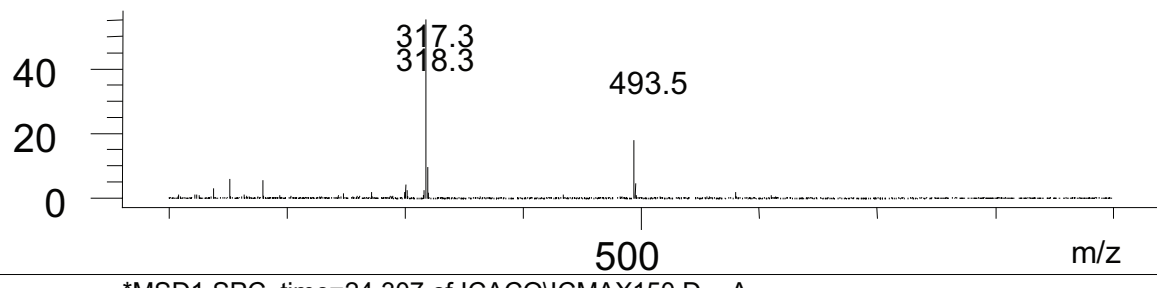

*MSD1 SPC, time=24.307 of ICACOIICMAX150.D A
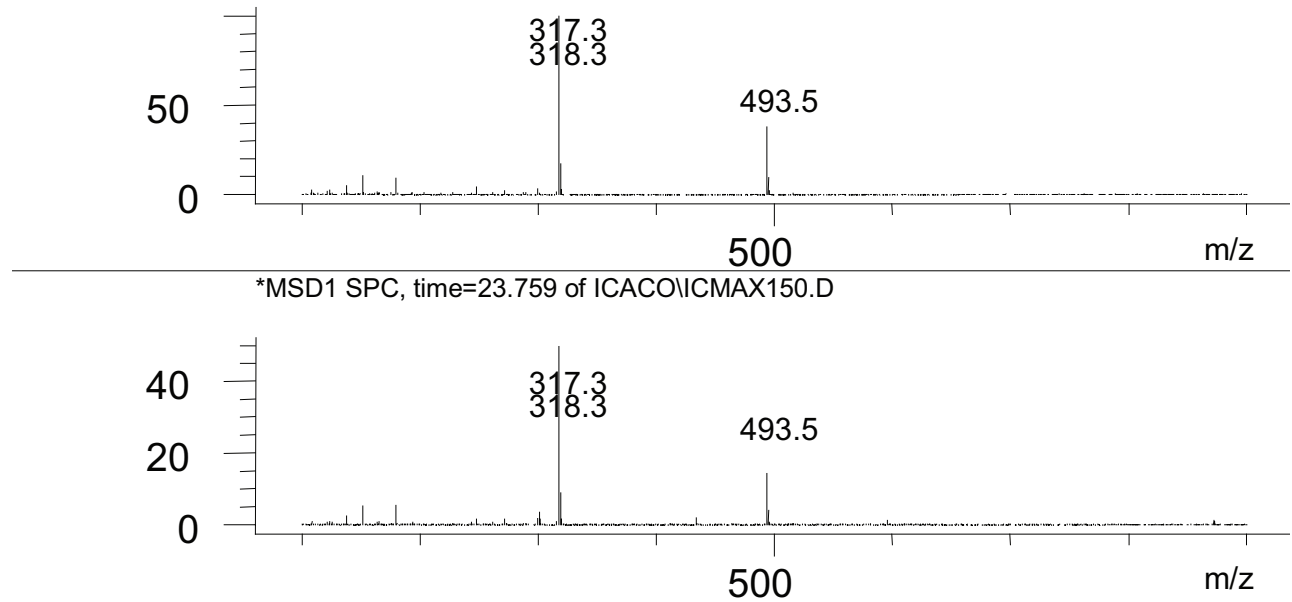

Figure 3. Mass spectrum of myricetin 3-O-glucuronide at different points of the peak to assess peak

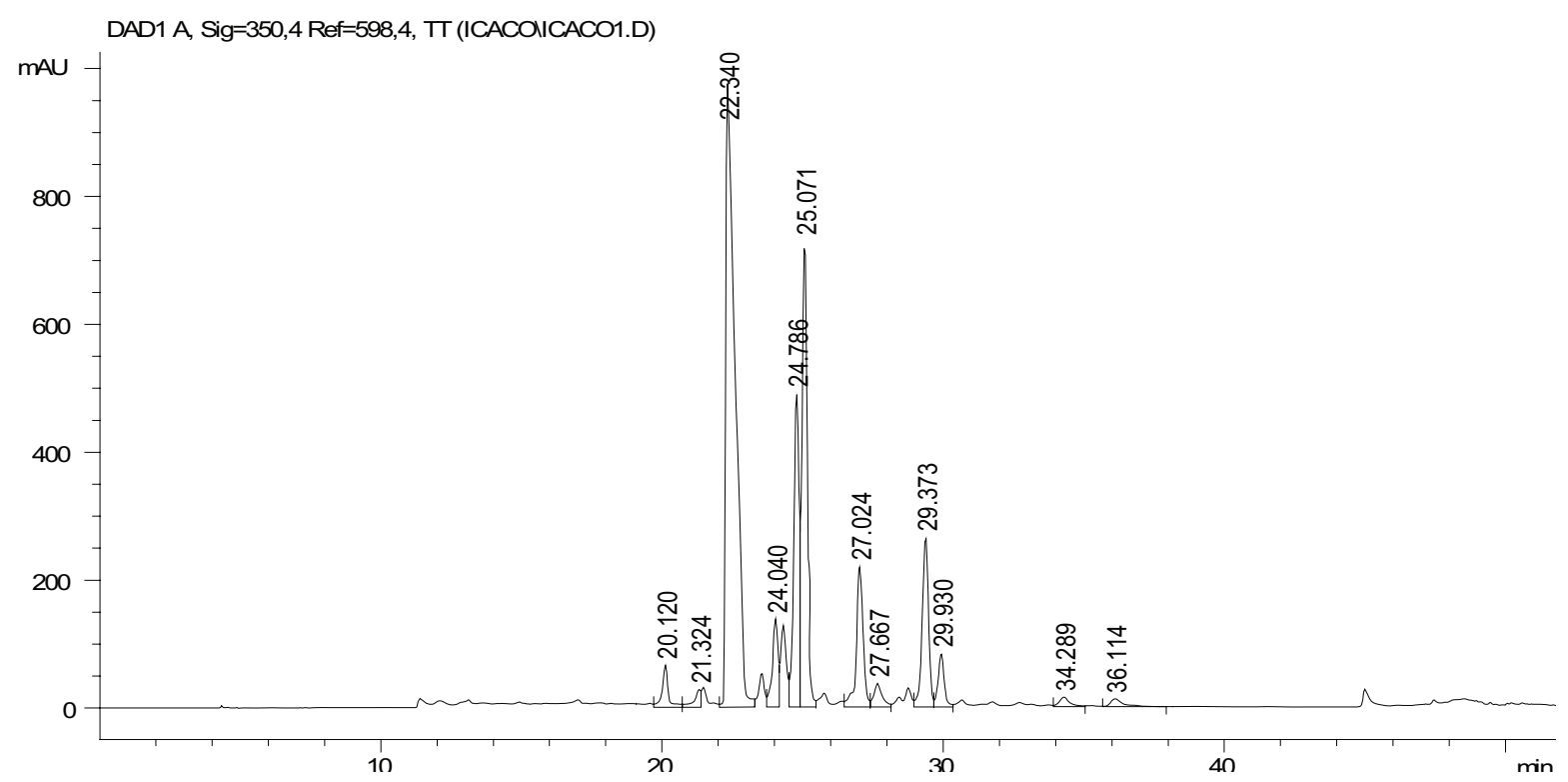

Figure 4. HPLC chromatograms acquired at $\lambda 350 \mathrm{~nm}$ of total hydroalcoholic extract of Chrysobalanus icaco L. leaves (column

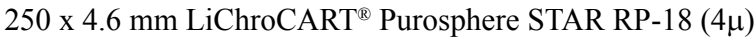

12) column. In particular, myricetin 3-O-glucuronide showed the most significant change. This could be due to the structure of myricetin 3-O-glucuronide which can decrease the strength of interaction with more lipophilic substrates such as the-Star ${ }^{\circledR}$ (RP-18) column phase with respect to MAX (RP-12) due to the presence of the glucuronic acid moiety. The other compounds showed, more or less, the same relationship of Rts obtained with the Synergy MAX column.

The large presence of myricetin derivatives 
in Chrysobalanus icaco L. leaves may also have an interesting ecological significance because its presence has been used as chemotaxonomic marker in the Chrysobalanaceae family (Mendez et al., 1995; Coradin et al., 1985).

Through the years, several studies have been done to investigate the various therapeutic biological effects of myricetin, including its use as a potent antioxidant, as an anticarcinogenic and antimutagenic agent, in the prevention of platelet aggregation, in cardiovascular diseases, antimicrobial properties against different bacterial strains, etc. (Kian et al., 1997). Myricetin derivatives have also been suggested to exhibit other relevant pharmacological activities such as those related to the generation of phenoxyl radicals in the inhibition of lipid peroxidation in rat hepatocyte culture (Morel et al., 1998; Aherne; O’Brien, 1999).

Finally, it was shown that myricetin has both a hypoglycaemic and hypotriglyceridemic effect in diabetic animals (Ong; Khoo, 2000) and could thus be of therapeutic value in diabetes. These data can explain the traditional use of Chrysobalanus icaco L. leaves.

\section{ACKNOWLEDGEMENTS}

We thank Dr. Mario Augusto Gonçalves Jardim Museu Paraense Emilio Goeldi, Belém, Pará, Brazil, for the identification of the plant material.

\section{REFERENCES}

Aherne SA, O'Brien NM 1999. The flavonoids, myricetin, quercetin and rutin, protect against cholestan$3 \beta, 5 \alpha, 6 \beta$-triol-induced toxicity in Chinese hamster ovary cell in vitro. Nutr Res 19: 749-760.

Barbosa WLR, Lima AP, Pinto LN 2001. Levantamento etnofarmacêutico da fitoterapia tradicional de Igarapé Mirí - Pará. VII Reunião Especial da Sociedade Brasileira para o Progresso da Ciência, Manaus, AM.

Barbosa WLR, Peres A 2002. Detecção e caracterização por cromatografia líquida de alta eficiência de rutina em extratos de Chrysobalanus icaco L. XVII Simpósio de Plantas Medicinais do Brasil, Cuiabá, MT.

Barbosa-Filho JM, Vasconcelos THC, Alencar AA, Batista LM, Oliveira RAG, Guedes DN, Falcão HS, Moura MD, Diniz MFFM, Modesto-Filho J 2005. Plants and their active constituents from South, Central, and North America with hypoglycemic activity. Rev Bras Farmacogn 15: 392-413.

Bate-Smith EC 1961. Chromatography and taxonomy in the Rosaceae, with special reference to Potentilla and Prunus. J Linn Soc London Bot 58: 39-54.

Chaffaud M, Emberger L 1960. Traite' de Botanique Systematique Vol. II, Masson, Paris.

Costa OA 1977. Brazilian plants with hypoglycaemic effects. Leandra 7: 63-75.

Coradin L, Giannasi DE, Prance AT 1985. Chemosystematic studies in the Chrysobalanaceae. Flavonoids in Parinari. Brittonia 37: 169-178.
Fernandes J, Castilho RO, Costa MR, Souza KW, Kaplan MAC, Gattass CR 2003. Pentacyclic triterpenes from Chrysobalanaceae species: cytotoxicity on multidrug resistant and sensitive leukaemia cell lines. Cancer Lett 190: 165-169.

Gunstone FD, Subbarao R 1967. New tropical seed oils. Part I. conjugated trienoic and tetraenoic acids and their oxoderivatives in the seed oils of Chrysobalanus icaco and Parinarium laurinum. Chem Phys Lipids 1: 349-359.

Gustafson KR, Munro MHG 1991. HIV inhibitory natural products: 3. Diterpenes from Homalanthus acuminatus and Chrysobalanus icaco. Tetrahedron 47: 4547-4554.

Kian C, Ong KC, Khoo HE 1997. Biological effects of myricetin (Review). Gen Pharmacol 29: 121-126.

Little EL-Jr, Woodbury RO, Wadswort FH 1974. Trees of Puerto Rico and the Virgin Islands, Agriculture Handbook 449, Vol.2. Washington, DC: U.S. Department of Agriculture.

Mendez J, Bilia AR, Morelli I 1995. Phytochemical investigations of Licania genus. Flavonoids and triterpenoids from Licania pittieri. Pharma Acta Helv 223-226.

Morel I, Abalea V, Sergent O, Cillard P, Cillard J 1998. Involvement of phenoxyl radical intermediates in lipid anti-oxidant action of myricetin in iron-treated rat hepatocyte culture. Biochem Pharmacol 55: 1399-1404.

Pereira NA 1997. Plants as hypoglycaemic agents. Ciência e Cultura 49: 354-358.

Ong KC, Khoo HE 2000. Effects of myricetin on glycaemia and glycogen metabolism in diabetic rats. Life Sci 1695-1705.

Romani A, Pinelli P, Galardi C, Mulinacci N, Tattini M 2002. Identification and quantification of galloyl derivatives, flavonoid glycosides and anthocyanins in leaves of Pistacia lentiscus L. Phytochem Anal 13: 79-86.

Verma VS, Raychaudhuri SP 1972. Effect of catechol tannins isolated from a medicinal plant Chrysobalanus icaco on the infectivity of potato virus X. Zentralbl Bakteriol Parasitenkd Infektionskr Hyg 127: 178179.

Yariwake JH, Lanças FM, Cappelaro EA, Vasconcelos EC, Tiberti LA, Pereira AMS, Franca SC 2005. Variabilidade sazonal de constituintes químicos (triterpenos, flavonóides e polifenóis) das folhas de Maytenus aquifolium Mart. (Celastraceae). Rev Bras Farmacogn 15: 162-168. 